\title{
Revenue, Trade and Welfare Effects Of the Comesa Free Trade Agreement on the Democratic Republic Of Congo
}

Patrick LUSENGE NDUNGO ( $\nabla$ patricklusenge@gmail.com )

Universite de Sherbrooke https://orcid.org/0000-0001-8922-5035

Gift Mugano

Nelson Mandela University

\section{Research}

Keywords: Revenue, Trade, Welfare, Partial Equilibrium Model, COMESA Free Trade Area (FTA), DRC

Posted Date: June 8th, 2020

DOI: https://doi.org/10.21203/rs.3.rs-32654/v1

License: (c) (i) This work is licensed under a Creative Commons Attribution 4.0 International License.

Read Full License 
Revenue, Trade and Welfare Effects Of the Comesa Free Trade Agreement on the Democratic Republic Of Congo

Lusenge Ndungo Patrick*1 2 and Mugano Gift ${ }^{1}$

\footnotetext{
${ }^{1}$ Department of Economics, Nelson Mandela University, Port Elizabeth, South Africa. ${ }^{2}$ Institute of Development Policy (IOB), University of Antwerp, Antwerp, Belgium.

Correspondence : patricklusenge@gmail.com
} 


\begin{abstract}
The present research attempts to assess the likely revenue, trade and welfare implications of the Common Market for Eastern and Southern Africa (COMESA) Free Trade Agreement (FTA) on the DRC. The study adopts a partial equilibrium model as the methodological approach. The findings of the research reveal that the COMESA FTA will be beneficial to the DRC in terms of an increase in exports and consumer welfare gain. Moreover, The WITS-SMART simulation results indicate that trade will be created in the DRC as a result of the COMESA FTA. Notwithstanding the fact that trade creation will have a positive effect on welfare, as the Congolese consumers would benefit from lower prices, some local industries in the DRC may be threaten of closure due to the lack of competitiveness. In addition, the simultation results show that the country will experience a huge fiscal revenue loss due to the implementation of zero per cent tarrif rate on imports duty from the COMESA trading partners. Finally, the simultation results indicate that trade will be diverted from more efficient and low cost nonmember states to high cost suppliers from the COMESA region. These findings shed light on policy implications.
\end{abstract}

Key words: Revenue, Trade, Welfare, Partial Equilibrium Model, COMESA Free Trade Area (FTA), DRC 


\section{INTRODUCTION}

Nowadays, many governments of developing countries have adopted to participate in regional integration agreements (RIAs). One type of RIAs can be a free trade agreement (FTA) which is a commitment by signatory members to remove trade barriers by applying zero tariffs on commodities produced across partner countries while maintaining different tariff regimes on imports from rest of the world (Plummer, Cheong and Hamanaka, 2011).

Theoretically, FTAs can result in a range of advantages for the trading partners such as open market access, trade creation and welfare gains as a result of lower prices. Moreover, other benefits of FTAs include : comparative advantage, employment, improvement of investment climate, intra-industry trade, monopoly prevention, economies of scale, production efficiencies, rising standard of living, greater variety of products, openness to investment and trade as a major catalyst of economic growth (Drozdz and Miškinis, 2011).

However, apart from these benefits, the implementation of FTAs may also bring negative results. These disadvantages can include : aggressive market entry policy, trade diversion, revenue loss, trade imbalance, economic instability, economic underdevelopment, inflexibility, higher and unfair competition, structural unemployment, difficult establishment of developing and new industries (Drozdz and Miškinis, 2011). Further, an FTA can also increase the complexity of the international trading system and raise transaction costs for business (Drozdz and Miškinis, 2011).

Regarding RIAs, the Democratic Republic of the Congo (DRC), which is the second largest country in the Africa continent with an area of 2,345,095 $\mathrm{km}^{2}$ and has approximately 80 million people, is part of three different regional communities : the Central African Economic Community (CEEAC), the Southern African Development Community (SADC) and the Common Market for Eastern and Southern Africa (COMESA). Its central location and connections with Africa's largest economic integration areas, such as the CEEAC, the COMESA and the SADC make it the perfect hub for business development and investment in the region (WTO, 2016). Moreover, the country has vast assets and natural resources in the soil and subsoil that make it an extraordinary land of opportunities for business and investment in a plethora of areas (WTO, 2016).

Notwithstanding the fact that the country is endowed with immense natural resources, $70 \%$ of the population live below the poverty line (Congo, 2006). Since the 1990s when war broke out 
in the DRC triggered by the control of natural resources, unemployment and poverty have been on the rise in the country (Erero, Pambudi and Bonga-Bonga, 2014). The country experienced a decade of recession with an average economic growth rate of -5.4 per cent between 1990 to 2001 (WTO, 2010).

Moreover, the DRC's trade integration ratio was 45.9 per cent during the 1990s compared to 92.8 per cent in 2007-higher than the average in low-income countries' $(80.1 \%)$ and SubSaharan countries (88.4\%) (Erero et al., 2014). From 1990 to 2001, imports stood average at 1,696,500,000 US Dollars, while exports stagnated at 1,538,300,000 US Dollars (WTO, 2010). The country's major exports are primary commodities while main imports are mining, machinery, transport equipment, and food products (Erero et al., 2014).

In 2001 the DRC's government has started to implement a number of measures in order to stabilize the macroeconomic situation, liberalize the Congolese economy, and open it up to international competition. Through all different reforms that have been implemented, the country is expecting to regain its place in the international trading system by relying on the market potential provided by its population of over 60 million and the numerous advantages deriving from its natural resources (WTO, 2010). As a result, the economy has started growing again with an economic growth rate of 5.5 per cent on average per year, driven mainly by the boom in the mining sector, communication and transportation, construction and public works, wholesale as well as retail trade (WTO, 2010). The country's trade balance has also recorded a significant increases in exports and imports of 94.0 per cent and 62.5 percent respectively in 2010 (WTO, 2016).

Recently, the parliament of the DRC has voted a law which allows the country to join the COMESA Free Trade Area (FTA). According to the agreement, the FTA will be implemented progressively through a three-year phase down approach of $40 \%$ reduction on duty which will be followed by two equal cuts of $30 \%$ (Osemo, 2016). Since the DRC is endowed with various mineral resources and a large market due to its population size; this accession to the FTA is expected to boost intra-regional trade and the levels of investment in the 19 partners countries (Osemo, 2016).

However, the COMESA FTA presents a serious challenge to the DRC economy because its local industry is still less competitive. Undoubtedly, domestic production may not be 
competitive as compared with finished products from countries with lower production costs. For instance, almost all traditional products (copper, cobalt, diamonds, coffee, crude oils, and wood) are exported either without being processed or with insufficient added value (WTO, 2010).

Moreover, the country does not gain from international trade of its own natural resources because much of them are illegally exported (Mosley and Chiripanhura, 2009). This limits the DRC's participation in the global economy while allowing for neighbouring countries and rebel groups to befenefit from these resources (Erero et al., 2014).

Finally, the DRC's government depends heavily on tariff revenues. In the case of the DRC, customs duties contribute in the range of 50 percent to government revenue (Makochekanwa, 2014). Therefore, any reduction in tariff revenues will significantly reduce government revenue with a negative impact on the state budget.

Considering the fact that the DRC has adopted significant trade liberalisation in the 1990s, however this did not result in any improvements (Erero et al., 2014), the question that comes to the fore is "Will joining the COMESA FTA be beneficiary for the DRC ?" More specifically, this study will attempt to answer to the following questions: Will the COMESA FTA lead to trade creation and diversion in the DRC? What will be its impact on imports and exports? Will the COMESA FTA lead to a loss of revenue for the DRC? What will be the gain in terms of welfare?

The aim of this study is to assess and discuss the expected impact of the COMESA FTA on the DRC. The rest of the research is structured as follows. Section two explores the literature review on economic integration and discusses the implications of a Free Trade Agreement (FTA) as a form of economic integration from an empirical perspective. The research methodology employed for the estimation and data issues are considered in section three. The fourth section presents and discusses the research findings, while the last section provides a conclusion and policy recommendations. 


\section{LITERATURE REVIEW}

Before the negotiation of free trade agreements (FTAs), it is also necessary and very crucial to conduct economic evaluation studies refer to as ex-ante studies. There is a large body of empirical research assessing the potential effects of an FTA. For instance, Othieno and Shinyekwa (2011) use also a partial equilibrium model based on the SMART simulations to investigate on the trade, welfare and revenue effects of the East African Community Customs Union Principle of Asymmetry on Uganda. The results reveal that the trade creation and welfare effects will increase over time. However, total imports will decline by 5.0 million US dollars due to the implementation of 10 per cent tariff reduction on goods of category B from Kenya (Othieno and Shinyekwa, 2011).

Moreover, Othieno and Shinyekwa (2011) find the tariff revenue loss would widen from US\$3.0 million in 2009 at 2 percent tariff line to a negative loss of about US\$5.3 million in 2010 as a result of the overall cost, insurance and freight (C.I.F) value of imports decreasing since duty free imports from Kenya will replace imports from non-member states (Othieno and Shinyekwa, 2011).

In their research, Pereira, Gómez and Herrera (2012) employ ex-ante partial equilibrium modeling approach to estimate the impact of the preferential trade agreement between Colombia and Canada. The findings indicate trade creation could be almost two times greater than trade diversion between the two countries. Moreover, intra trade is expected to boost by approximately $10 \%$ during the first year of the agreement and will be focussed on a small number of goods, while trade diversion will be stronger with the largest trading partner of each partner, mainly the United States (Pereira et al., 2012).

Again, Choudhry, Kallummal and Varma (2012) use also a partial equilibrium approach based on SMART simulations to evaluate the trade creation and trade diversion effects of the India Sri-Lanka FTA (ISFTA). The findings indicate that there will be substantial trade creation between partner countries than trade diversion among non-partner countries. To illustrate just for articles of apparel and clothing accessories, the estimated trade creation is about 0.555 million US Dollars, while trade diversion is around 0.248 million US Dollar (Choudhry et al., 2012). 
In their study, Onogwu and Arene (2013) use partial equilibrium modelling approach to evaluate the likely revenue, trade and welfare implications of a free-trade economic-partnership agreement (EPA) between Cape Verde and the European Union (EU). Onogwu and Arene (2013) find that Cape Verde would lose about 35\% of its total revenue as a result of the dismantling of tariff on the Cape Verdean's imports from the EU. Although the Cape Verdean's imports from the EU are expected to increase, welfare gains are likely to decline as trade diversion outweighs trade creation (Onogwu and Arene, 2013).

Makochekanwa (2014) examines the implementations of the COMESA-EAC-SADC tripartite free trade area (T-FTA) on the 26 member states using by using a partial equilibrium model based on SMART simulations. The results show that the T-FTA is expected to create around 2 billion US dollars worth of new trade for the 26 participating member countries, with Angola and DRC as the big winners. Nevertheless, a positive net trade effect of US\$1.5 billion is expected across the 26 countries since only US\$454 million of trade will be diverted from lowcost suppliers to high-cost producers in the trading bloc, while around 1 billion US dollars revenue will be lost following removal of import duties (Makochekanwa, 2014).

Another study that employs a partial equilibrium model based on WITS-SMART simulations is by Ousmane (2015) whose purpose was to assess the economic impact on Niger of the trade component of the Economic Partnership Agreements (EPAs) between ECOWAS and the European Union. After simulating several scenarios of trade liberalization, the findings indicate Niger is likely to experience a net trade creation of US\$22.590 million, while the country is expected to suffer from a loss in customs revenues of close to US\$24 million (Ousmane, 2015).

More recently, Guei, Mugano and le Roux (2017) use a partial equilibrium model based on WITS-SMART simulations to assess the impact the European Union FTA on South Africa. Their findings indicate a total welfare effect valued at US\$134 million coupled with US\$1.036 billion of total trade effects (Guei, Mugano, \& le Roux, 2017). Nevertheless, South Africa is likely to experience a revenue loss amounting to US\$ 562 million (Guei et al., 2017).

After analysing different case of studies, it appears that the findings differ slightly in some cases and substantially in others. This variation can be explained by differences in economic structures, geography features and internatioanl economic relations with the rest of the world. 
Therefore, it can be argued that the implications of an FTA depend on a number of economic issues, such as the initial tariff structure of a country and its trade pattern (Mugano, 2015).

Although a considerable number of ex-ante studies have been carried out to assess the potential impact the COMESA FTA on its member countries, the outcomes of such an agreement in terms of revenue, trade and welfare effects vary from one country to another country. Accordingly, it follows that impact assessments of the COMESA FTA conducted in other countries or in the COMESA region as a whole cannot be used to benchmark the DRC's tradepolicy reforms. Therefore, it is necessary to undertake a research that investigates on the likely impact of the COMESA FTA on revenue, trade and consumers welfare in the DRC. And this is the main purpose of this research.

According to the researcher's knowledge, so far there is no specific study yet that focuses on revenue, trade and welfare effects of COMESA FTA in the DRC. Hence, this study fills this gap by conducting in-depth analysis on the implications of the COMESA FTA on the DRC in terms of trade creation, trade diversion, import, export, revenue and consumers welfare.

\section{Research methodology}

\subsection{Model framework}

To assess the revenue, trade and welfare effects of COMESA FTA on the DRC, this study sets up a theoretical framework following Laird and Yeats (1986), and Jammes and Olarreaga (2005). The specification is based on a partial equilibrium model that relies on the Armington assumption, that is, the imports from different countries are imperfect substitutes, while export elasticities are infinite, that is, export supplies are perfectly elastic (Jammes and Olarreaga, 2005). Accordingly, all price changes are fully transmitted when non-tariff and tariff distortions are reduced or removed since world prices of each type of goods are given in the market.

In order to derive the first-round effects of the simulated policy changes, the current study specifies a partial equilibrium model based on import demand $(M)$ and export supply $(X)$ functions as described by Laird and Yeats (1986) as well as Jammes and Olarreaga (2005) :

(1) $M_{i j k}=f\left(Y_{j}, P_{i j}, P_{i k}\right)$ 
Equation (1) implies that the DRC's imports demand $j$ for the commodity catogory $i$ manufactured or produced in the COMESA member $k$ 's state are function of their prices and the total expenditure on the category. In equation (1), $Y_{j}$ the DRC's total import expenditure on commodity $i$ and $P_{i j}$ is the domestic price of commodity $i$, whereas $P_{i k}$ representes the price of commodity $i$ in the partner $k$ 's country, that is, the price that includes tarrif.

The producer partner country $k$ 's export supply function for commodity $i$ can be specified as:

(2) $X_{i j k}=f\left(P_{i k j}\right)$

Where $X_{i j k}$ represents exports of commodity $i$ by the partner $k$ 's countries and $P_{i k j}$ is the price of commodity $i$ from partner country $k$ to the DRC (country $j$ ).

The partial equilibrium in the market will be established by the following identity :

(3) $M_{i j k}=X_{i k j}$

In the case of a free trade agreement (FTA), the domestic price of the commodity $i$ in the importing market $j$ will be equal to exporting country $k$ 's export price plus transport and insurance charges, it follows that this price will rise by an amount equivalent to the ad valorem incidence of any tariff or non-tariff distortion applied to the goods (Laird and Yeats, 1986). Therefore, the domestic price of commodity $i$ in the DRC from its trading partners would change with the change in an ad valorem tariff as described in equation (4) below :

(4) $P_{i j k}=P_{i k j}\left(1+t_{i j k}\right)$

Where $P_{i j k}$ is the price of commodity $i$ in the DRC from its trading partners $k$, that is, domestic price in $j$ and $t_{i j k}$ stands for the tariff imposed by the DRC (country $j$ ) on its imports of commodity $i$ from the partner $k$ 's countries.

Accordingly, the export revenues earned by the exporting country $k$ will be specified as follows:

(5) $R_{i k j}=X_{i k j} \cdot P_{i k j}$ 
Where $R_{i k j}$ represents the export revenues on commodity $i$ from the trading country $k$ to country $j$ (the DRC in this case). The above specification of equations (1) - (5) form together the basic model from which will be derived the trade creation, trade diversion, total or net trade, revenue and welfare effects.

\subsubsection{Trade creation effect}

As strictly defined by Viner, the trade creation effect is the reduction in national production that is replaced by more-efficient participating country production (Plummer et al., 2011). More specifically, the trade creation effect will be captured by the increased demand for commodity $i$ in the DRC from its $k$ COMESA trading partners due to the full transmission of price changes together with the price decrease when non-tariff or tariff distortions are reduced or removed on $i$ product.

Therefore, the trade creation (TC) effect is given as follows :

(6) $T C_{i j k}=M_{i j k} \cdot E m \cdot \frac{d t_{i j k}}{1+t_{i j k}} \cdot\left[1 \cdot\left(\frac{E m}{E x}\right)\right]$

It may be noted that if the elasticity of export supply with respect to the world price is infinite then the denominator on the right hand side of equation (6) becomes unity and can be ignored (Laird and Yeats, 1986).

\subsubsection{Trade diversion effect}

In the creation of a free trade area (FTA), trade diversion effect occurs when more efficient non-participating imports are replaced by less efficient member states imports (Plummer et al., 2011). Particularly in the cas of the DRC, the trade diversion effect would occur if more efficient producers from the rest of the world are replaced by inefficient suppliers from the COMESA FTA partner countries.

The trade diversion (TD) effect can be measured by equation (7) as follows : 
(7) $T D_{i j k}=\frac{M_{i j k}}{\sum M_{i j k}} \cdot \frac{\sum M_{i j k} \cdot \sum M_{i j K} \cdot E s \cdot \frac{d\left(P_{i j k} / P_{i j K}\right)}{P_{i j k} / P_{i j K}}}{\sum M_{i j k}+\sum M_{i j K}+\sum M_{i j k} \cdot E s \cdot \frac{d\left(P_{i j k} / P_{i j K}\right)}{P_{i j k} / P_{i j K}}}$

This expression (7) represents the change in imports from one country or trade diversion gain or loss, as a result of the change in duty paid prices relative to the prices from other sources resulting from a commercial policy change (Laird and Yeats, 1986).

\subsubsection{Revenue effect}

Regarding the revenue effect of a Regional Integration Agreement (RIA), Schiff and Winters (2003) argue that membership in an RIA erodes tariff revenue in two ways: directly, as tariffs on intra-RIA trade are reduced to zero per cent, and indirectly, when trade diversion occurs, as importers switch away from the rest of the world imports subject to tariffs (Schiff and Winters, 2003).

Theoretically, the tarrif revenue can be estimated by multiplying the tarrif rate or simply tax and the tax base, that is, value of imports (Mugano, 2013a). Assuming that the export supply elasticity is less than the infinite, the percentage increase in revenue is given by adding together the percentage increase in exports and the percentage increase in prices (Laird and Yeats, 1986). Therefore, the equation (8) below gives the revenue effect as a result of a full tariff elimination towards the COMESA FTA.

(8) $\frac{d R_{i k j}}{R_{i k j}}=\frac{d M_{i j k}}{M_{i j k}}+\frac{d P_{i k j}}{P_{i k j}}$

Alternatively, the expession for the revenue effect can be written as follows:

(9) $\frac{d R_{i k j}}{R_{i k j}}=\left(\frac{d t_{i j k}}{1+t_{i j k}}\right) \cdot E m \cdot\left(\frac{1+E x}{E x-E m}\right)$

\subsubsection{Consumer Welfare Effect}

The welfare effect originates from the consumers gains in the importing country, as a result of the lower domestic prices due to the removal or reduction of tariffs or the ad valorem incidence of non-tariff distortions (Laird and Yeats, 1986). 
Let us now denote $W_{i j k}$ as the welfare benefit of commodity $i$ in country $j$ (the DRC) from country $k$ (the COMESA partner countries) and $\lambda$ the weight which captures the decline and resurgence of protectionist behaviours among partner countries. Therefore, this welfare benefit can be written as follows:

$$
W_{i j k}=\lambda(\text { static welfare gains })
$$

Since the net welfare gain is computed as the increase in import value multiplies by the average of the ex-ante and ex-post ad valorem incidence of the trade barriers' dismantling, a further specification of the equation (10) above gives :

$$
W_{i j k}=\lambda\left(d t_{i j k} \cdot d M_{i j k}\right)
$$

Assuming that the welfare impact lasts from one year to a year and a half, the weight $\lambda$ should roughly be equal to 0.5 since a dollar's worth of static welfare gain should be able to offset a dollar's worth of trade deficit in the short-run (Chan, 1985). Thus, the welfare gain is considered as the increase in consumer surplus and therefore can be written :

$$
W_{i j k}=0.5\left(d t_{i j k} \cdot d M_{i j k}\right)
$$

Since the economy of the DRC has no major influence on world prices, the equation (21) above assumes that the elasticity of export supply is infinity.

\subsection{Estimation Procedure}

\subsubsection{The World Integrated Trade Solution and Software for Market Analysis and Restrictions on Trade}

To estimate the ex-ante revenue, trade and welfare effects of the COMESA FTA, the World Integrated Trade Solution and Software for Market Analysis and Restrictions on Trade (WITSSMART) is used in this study. The WITS-SMART is a ready-made partial equilibrium (PE) model developed by the World Bank in close collaboration and consultation with the United Nation Conference on Trade and Development (UNCTAD), the International Trade Centre (ITC), the United Nations Statistics Division (UNSD) and the World Trade Organisation (WTO). 
The Armington assumption, which assumes that the imports from different countries are imperfect substitutes, is held in the WITS-SMART model. Therefore, this study retains a value of 1.5 as the elasticity of substitution for each commodity (Amjadi A, Schuler P, Kuwahara H. and Quadros, S., 2011). This value implies that the same goods from different countries are assumed to be imperfect substitutes (Makochekanwa, 2014).

Regarding the export supply elasticities, SMART model can either consider world prices of each type of commodities as given, that is, export supplies are perfectly elastic or simply assume an upward-sloping export supply curves (Bacchetta et al., 2012). In the current study, the export supply elasticity is set at infinite, that is, a value of 99 (Amjadi et al., 2011). This implies that the DRC is a price-taker in the world market.

\subsubsection{Scenario}

The scenario retained in this study is based on complete removal of all tariff lines between the DRC and its trading partners from the COMESA. The DRC's trading partners from the COMESA include Burundi, Comoros, Djibouti, Egypt, Eritrea, Ethiopia, Kenya, Libya, Madagascar, Malawi, Mauritius, Rwanda, Seychelles, Sudan, Swaziland, Uganda, Zambia and Zimbabwe.

\subsubsection{Sensitivity Analysis and Robustness Test}

A common feature of the WITS-SMART results as well as those of others partial and general equilibrium models is that they depend on the assumptions made and parameter values, that is, the values of elasticities used. Therefore, the current study perform a manual robustness test by modifying the value of elasticities over a reasonable range since the WITS-SMART model does not provide a built-in sensitivity analysis (Plummer et al., 2011).

Accordingly, the sensitivity analysis is carried out by using various elasticities values from Stern, Francis and Schumacher (1976) and Tokarick (2014) as suggested in Mugano (2015). Table 3-1 below provides a range values for the export supply and the import demand elasticities as well as the elasticity of substitution used in the current study. 
Table 3 1: Elasticities Used in Sensitivity Analysis.

\begin{tabular}{|l|r|r|r|r|}
\hline Elasticities & \multicolumn{1}{l|}{ Lower bound } & \multicolumn{1}{l|}{ Base-case } & Upper bound & \multicolumn{1}{l|}{ Worst case } \\
\hline Substitution & 0.5 & $1.44 * * *$ & 2 & 6 \\
\hline Export supply & 89.1 & 99 & $99 * *$ & $99 * *$ \\
\hline Import demand* & 2.7 & 1.5 & 3.3 & 6 \\
\hline
\end{tabular}

Source: *(Stern et al., 1976) and ***(Tokarick, 2014) cited in Mugano (2015).**Hold infinite.

\subsection{Data Sources}

Regarding the data issue, this study relies on the WITS data base that include the following sources: the common format for transient data exchange (COMTRADE), the trade analysis information system (TRAINS), the world trade organization integrated database (IDB-WTO) and consolidated tariff schedule (CTS-WTO).

Following its structure, the WITS database contains statistic information at the 6-digit level of the Harmonised System (HS) on variables such as: the import and export values from/to each partner countries, the export supply and the import demand elasticities for goods as well as the elasticity of substitution between various commodities and the tarrif applied by each countries. For the purpose of this study, the WITS 2010 data base was selected since it is the most recent that provides full statistic information on the DRC and its trading partner from the COMESA countries.

\section{Research findings and discussion}

\subsection{The Trade-Creating and Trade-Diversiting Effects of the COMESA FTA}

On one hand, the trade-creating effects implies that more efficient or lower-cost foreign suppliers in any of the COMESA partner country will automatically displace the less efficient or higher-cost local suppliers in the DRC. As a result, not only the Congolese consumers would benefit from facing lower prices but also real resources will be saved by displacing the source of supply to any COMESA country based on comparative advantage. However, some local producers in the DRC would be harmed since their products will be replaced by cheaper products from other countries in the COMESA region. On the other hand, the trade-diverting effects means that the COMESA partner country production may displace more efficient and lower-cost imports from the rest of the world (ROW). For the DRC, this implies that more resources will be required to purchase the same product from a COMESA partner, which is clearly costly for the country. 
The trade creation and trade diversion simulation results from the WITS-SMART are presented in Table 4.1 below as follows :

Table 42 : Trade Creation and Trade Diversion Effects of the COMESA FTA on the DRC (US\$ million)

\begin{tabular}{|l|r|r|r|}
\hline Partner Country & Trade Creation Effect & Trade Diversion Effect & Total Trade Effect \\
\hline Burundi & 4.94 & 0.86 & 5.80 \\
\hline Egypt, Arab Rep. & 3.39 & 0.65 & 4.03 \\
\hline Kenya & 79.88 & 11.84 & 91.72 \\
\hline Madagascar & 0.12 & 0.05 & 0.16 \\
\hline Malawi & 0.07 & 0.05 & 0.12 \\
\hline Rwanda & 10.82 & 1.45 & 12.27 \\
\hline Uganda & 104.16 & 14.77 & 118.93 \\
\hline Zambia & 113.42 & 18.88 & 132.30 \\
\hline Zimbabwe & 5.30 & 0.93 & 6.23 \\
\hline Total & $\mathbf{3 2 2 . 1 0}$ & $\mathbf{4 9 . 4 7}$ & $\mathbf{3 7 1 . 5 7}$ \\
\hline
\end{tabular}

Source : Author's Calculations Based on WITS-SMART Simulations.

As indicated in the table 4.1, around US\$322 million trade will be created in the DRC as a result of the COMESA FTA. Makochekanwa (2014) estimates a trade creation effect amounting to US\$783 million in the DRC, that is, more than double trade could be created in the case of the tripartite free trade area (T-FTA).

Following the 100 percent reduction in import duties across the COMESA FTA member states, a total of US $\$ 49.47$ million worth of trade will be diverted from low cost non-partner countries to be replaced by high cost and less efficient partner countries in the FTA bloc (see Tableau 4.1). This outcome is not statistically different from Makochekanwa's findings whose research finds a trade diversion effect of US\$56.9 million for the DRC in the case of the T-FTA.

Nevertheless, trade creation is expected to outweigh trade diversion with a total trade effect of approximately US\$372 million (see Figure 4.1). The major DRC's trading partner in the COMESA region are mainly, Zambia, Uganda and Kenya with 92.30 per cent of the total trade effect. 


\section{Figure 41 Trade Creation versus Trade Diversion Effects (US\$ million).}

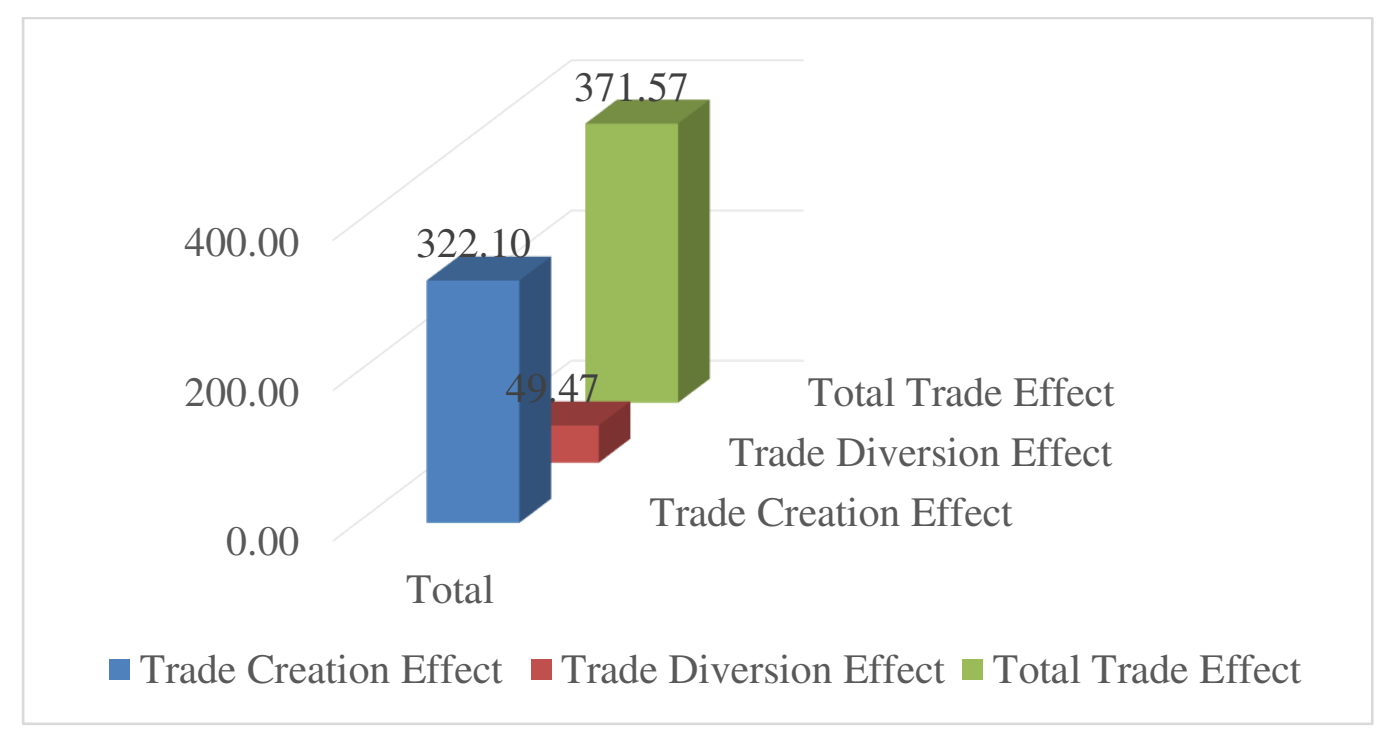

Source : Author's Drawing Based on WITS-SMART Simulations.

Notwithstanding the fact that the free trade agreement is expected to enlarge the market for the COMESA countries in the DRC, many countries outside of the trading union will lose their market as a result of trade diversion. The agreement will result in shifting the DRC's imports away from the ROW to the COMESA partner imports. Table 4.2 below presents the top ten losers of the COMESA FTA.

Table 43 : The Top Ten Countries that Lost their Market in the DRC due to the COMESA FTA (US\$ Million)

\begin{tabular}{|l|c|}
\hline Partner Country & Trade Diversion Effect \\
\hline South Africa & -14.27 \\
\hline China & -7.37 \\
\hline Tanzania & -6.42 \\
\hline Brazil & -4.19 \\
\hline Belgium & -3.71 \\
\hline Cote d'Ivoire & -2.67 \\
\hline Turkey & -1.67 \\
\hline Malaysia & -1.41 \\
\hline France & -1.13 \\
\hline Netherlands & -0.92 \\
\hline
\end{tabular}

Source : Author's Calculations Based on WITS-SMART Simulations.

As shown in Table 4.2, South Africa will experience the highest trade diversion with a loss estimated to US\$14.27 million. This is not surprising since South Africa with countries such as China, Belgium, France and the United States are the DRC's main trading partners. Among the 
losers, South Africa will be followed by China, Tanzania, Brazil and Belgium with diverting effects of US\$7.37 million, US\$6.42 million, US\$4.19 million and US\$3.71 million respectively. Other countries such as Cote d'Ivoire, Turkey, Malaysia, France and Netherlands will experience a total loss estimated to US\$7.79 million, meaning that on average US\$1.56 million of trade will be diverted from low cost suppliers in each of these countries towards less efficient producers in the COMESA FTA counties.

Table 4.3 below gives more detail about the top ten products that would have the highest trade creation effects in the country.

Table 44 : The Ten Products with the Highest Trade Creation Effects in the DRC (US\$ Million)

\begin{tabular}{|c|l|r|}
\hline HS Code & \multicolumn{1}{|c|}{ Product Description } & \multicolumn{1}{|c|}{ Value } \\
\hline 72 & Iron and Steel & 97.15 \\
\hline 11 & Products of the milling industry, Malt and Wheat Gluten & 68.93 \\
\hline 25 & Salt, sulphur, earth and stone, plastering material, lime and cement & 30.37 \\
\hline 10 & Cereals & 8.82 \\
\hline 24 & Tobacco and manufactured Tobacco Substitutes & 8.73 \\
\hline 17 & Sugars and Sugar Confectionery & 8.56 \\
\hline 34 & Soap, Artificial Waxes, Candles and Similar Articles & 8.03 \\
\hline 01 & Live Animals & 6.19 \\
\hline 36 & Explosives and Pyrotechnic Products & 3.52 \\
\hline 68 & Articles of Stone, Plaster and Cement & 3.05 \\
\hline Other & & 78.74 \\
\hline Total & & $\mathbf{3 2 2 . 1 0}$ \\
\hline
\end{tabular}

Source : Author's Calculations Based on WITS-SMART Simulations.

Table 4.3 above shows that three-fifths of the major products which are expected to benefit from market access in the DRC as a result of the COMESA FTA are : firstly, iron and steel ( almost 91 per cent of corrugated); secondly, wheat or meslin and maize (corn) flour; and thirdly, salt, sulphur and kaolin with imports values of US\$97.15 million, US\$68.93 million and US\$30.37 million respectively. With 30 per cent of trade-creating effect, iron and steel is expected to come as a relief to Congolese consumers followed by products of the milling industry which represent around 21 per cent of the total share (see Figure 4.2). 
Figure 42 Share of the Top Ten Trade-Creating Products (\%).

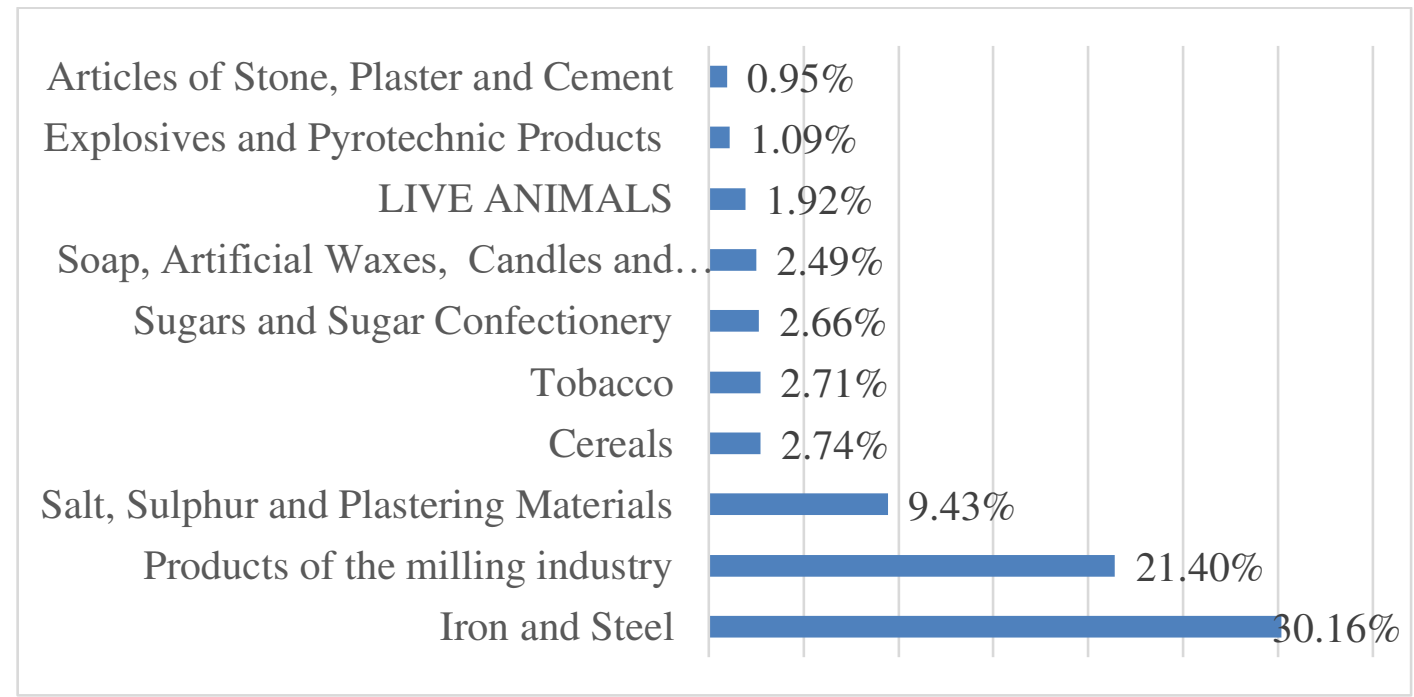

Source : Author's Drawing Based on WITS-SMART Simulations.

However, this trade creation effect could be harmful for the local industry since the domestic production would stop as the local market is vacated for a COMESA partner. For instance, the iron and steel national industry, which is currently in his recovery phase with an investment of US\$100 million for the rehabilitation of the Maluku steel plant (COPIREP, 2012), will be theatened with closure due to the high competitiveness of iron and steel products from the COMESA countries. Thus, the government should come up with a financial package to mitigate costs of foreign competition and also enhance the competitiveness of the affected industry (Mugano, 2015).

Since the DRC government has agreed to implement the COMESA FTA gradually, it is necessary for the country to define a list of products that would be exempted from the tariff reductions based on the results from Table 4.3. Therefore, the government may enact these lists called "sensitive" lists as a mean to protect domestic industries from foreign competition (Kumar and Ahmed, 2014).

In addition to this side effect of trade creation, Table 4.4 below presents the top ten most vulnerable products to trade diversion, that is, the lower cost imports from outside of the COMESA region that may cease in the DRC due to their replacement by higher cost imports from a partner country. 
Table 45 :The Top Ten most Vulnerable Products to Trade Diversion (US\$ Million)

\begin{tabular}{|c|l|r|}
\hline HS Code & \multicolumn{1}{|c|}{ Product Description } & \multicolumn{1}{|c|}{ Value } \\
\hline 25 & Salt, sulphur, earth and stone, plastering material, lime and cement & 4.52 \\
\hline 17 & Sugars and sugar confectionery & 4.51 \\
\hline 87 & Vehicles other than railway and accessories thereof & 2.99 \\
\hline 39 & Plastics and articles thereof & 2.79 \\
\hline 11 & Products of the milling industry, malt and wheat gluten & 2.72 \\
\hline 73 & Articles of iron or steel & 2.54 \\
\hline 27 & Mineral fuels, oils and bituminous substances & 2.54 \\
\hline 15 & Animal or vegetable fats and oils & 2.52 \\
\hline 22 & Beverages, spirits and vinegar & 2.48 \\
\hline 34 & Soap, artificial waxes, candles and similar articles & 2.48 \\
\hline Other & & 19.36 \\
\hline Total & & $\mathbf{4 9 . 4 7}$ \\
\hline
\end{tabular}

Source : Author's Calculations Based on WITS-SMART Simulations.

In Table 4.4, the results shows that there would be a negative effect on trade for the products such as salt, quicklime and white cement, cane sugar, vehicles accessories thereof, plastics and articles thereof, wheat or meslin flour, articles of iron or steel, mineral oils, animal or vegetable oils, beer made from malt and soap products which represent a value of US\$30.11 million, that is, around 60 per cent of trade diversion.

Overall, products from the COMESA trading partners that represents an import value of US\$49.47 million are less competitive than those from the rest of the World (ROW). This outcome is consistent with Othieno and Shinyekwa (2011) who find trade diversion effect will be driven by the products such as soap products, cement, paper products, plastics and articles thereof, iron and steel in the case of Uganda-East African Community (EAC) custom union (Othieno and Shinyekwa, 2011).

\subsection{Revenue Effect}

Joining the COMESA FTA may erode the DRC's government revenues in two ways: directly, as tariffs on intra-bloc trade will be reduced to zero per cent, and indirectly through trade diversion, as some importers may switch away from the imports of the ROW which will remain subject to tariffs.

The zero per cent tarrif that have to be implemented by the DRC to conform to the COMESA FTA will result in a huge fiscal revenue loss amounting to US\$107.01 million as indicated in 
Table 4.5 below. This amount could even double under the tripartite free trade area (T-FTA), that is, US\$214.4 million as estimated by Makochekanwa (2014).

Table 65 : Revenue Effect of the COMESA FTA on the DRC (US\$ Million)

\begin{tabular}{|c|l|r|r|}
\hline HS Code & \multicolumn{1}{|c|}{ Product Description } & $\begin{array}{l}\text { Revenue } \\
\text { Loss }\end{array}$ & $\begin{array}{l}\text { \% of Total } \\
\text { Loss }\end{array}$ \\
\hline $\mathbf{1 7}$ & Sugars and Sugar Confectionery & -14.41 & 13.46 \\
\hline $\mathbf{2 5}$ & Salt, sulphur, earth and stone, plastering material, lime and cement & -13.45 & 12.57 \\
\hline $\mathbf{3 9}$ & Plastics and Articles Thereof & -7.79 & 7.28 \\
\hline $\mathbf{7 2}$ & Iron and Steel & -6.77 & 6.32 \\
\hline $\mathbf{2 2}$ & Beverages, Spirits and Vinegar & -5.10 & 4.77 \\
\hline $\mathbf{1 5}$ & Animal or Vegetable Fats and Oils & -4.96 & 4.64 \\
\hline $\mathbf{3 4}$ & Soap, Artificial Waxes, Candles and Similar Articles & -4.49 & 4.20 \\
\hline $\mathbf{2 7}$ & Mineral Fuels, Oils and Bituminous Substances & -4.39 & 4.10 \\
\hline $\mathbf{8 7}$ & Vehicles other than Railway and Accessories Thereof & -3.67 & 3.43 \\
\hline $\mathbf{1 1}$ & Products of the milling industry, Malt and Wheat Gluten & -3.64 & 3.40 \\
\hline Other & & -38.33 & 35.82 \\
\hline Total & & $\mathbf{- 1 0 7 . 0 1}$ & $\mathbf{1 0 0 . 0 0}$ \\
\hline
\end{tabular}

Source : Author's Calculations Based on WITS-SMART Simulations.

Table 4.5 shows that 26.04 per cent of the expected revenue loss, that is, US $\$ 27.86$ million will be due to the subsequent tariff cut on products like cane sugar, salt, quicklime and white cement. Moreover, plastics articles such as polymers of ethylene, articles of iron or steel and beverages, mostly beer made mostly from malt represent US $\$ 19.66$ million, that is, 18.38 per cent of the total revenue loss. An additional 12.94 per cent contribution to the revenue loss will be related to products like animal or vegetable oils, soap products, light oils, coke or semi-coke of coal and other mineral oils for a value of US\$13.84 million, whereas only US\$7.30 million will result from tariff cut on vehicles accessories thereof and wheat or meslin flour, that is, 6.83 per cent of the total revenue loss.

Since there is a certain similarity between the list of products in Table 4.5 and in those in Tables 4.3 and 4.4 , this suggests that the loss of government revenue is driven directly by the intraCOMESA trade and indirectly by the trade diversion effect following Schiff and Winters' theoretical expectation. These findings are also consistent with empirical evidence from Othieno and Shinyekwa (2011) who show that the revenue losses in the case of Uganda-EAC custom union are due to the progressive intra-tariff cuts associated with the decline in the import value (Othieno and Shinyekwa, 2011). 
From the above-mentioned results, it is crucial to remind that all this expected revenue loss will be due to duty free imports from the COMESA partner countries. Therefore, as said in the previous section, the Congolese government could define the so-called "sensitive" lists based on the results from Table 4.5 as a mean to preserve tariff revenues.

Furthermore, the implementation of the COMESA FTA in the DRC will also need to be accompanied by fiscal reforms to improve the tax-collection system from sales or value-added taxes (VAT) and domestic excise so that the revenue shortfall described would be offset. For instance, with regards to domestic taxation, the DRC's government plans to assess the reform that introduced VAT in January 2012 (WTO, 2016). The assessment should lead to improvements in VAT collection mechanisms and the diversification of VAT rates, for example reducing the rate on staple products such as foodstuffs (WTO, 2016).

\subsection{Consumer Welfare Effect}

Snorrason (2012) stresses that the relative magnitudes of trade creation and trade diversion will be imporant in order to determine whether or not a trade union is welfare improving. In the case of the DRC, the findings in the second sub-section have demonstrated that trade creation outweighes trade diversion, meaning that the Congolese consumers will benefit from the COMESA FTA. The welfare effect estimated in the SMART, which is measured as the consumer surplus or consumers' net benefit from the market as a result of lower prices, is presented in Table 4.6 below.

Table 76 : Welfare Effect of the COMESA FTA on the DRC (US\$ Million)

\begin{tabular}{|c|l|r|r|}
\hline $\begin{array}{c}\text { HS } \\
\text { Code }\end{array}$ & \multicolumn{1}{|c|}{ Product Description } & $\begin{array}{c}\text { Welfare of } \\
\text { Gain }\end{array}$ & $\begin{array}{c}\text { GDP* in } \\
\mathbf{2 0 1 0}\end{array}$ \\
\hline 72 & Iron and Steel & 9.78 & 0.048 \\
\hline 11 & Products of the milling industry, Malt and Wheat Gluten & 4.42 & 0.022 \\
\hline 25 & Salt, sulphur, earth \&stone, plastering material, lime and cement & 2.31 & 0.011 \\
\hline 24 & Tobacco and manufactured Tobacco Substitutes & 1.12 & 0.005 \\
\hline 17 & Sugars and Sugar Confectionery & 0.96 & 0.005 \\
\hline 34 & Soap, Artificial Waxes, Candles and Similar Articles & 0.92 & 0.004 \\
\hline 27 & Mineral Fuels, Oils and Bituminous Substances & 1.11 & 0.005 \\
\hline 10 & Cereals & 0.51 & 0.002 \\
\hline 68 & Articles of Stone, Plaster and Cement & 0.33 & 0.002 \\
\hline 36 & Explosives and Pyrotechnic Products & 0.36 & 0.002 \\
\hline Other & & 6.66 & 0.032 \\
\hline Total & & $\mathbf{2 8 . 4 9}$ & $\mathbf{0 . 1 4}$ \\
\hline
\end{tabular}

Source : Author's Calculations Based on WITS-SMART Simulations, *US\$20.52 billion. 
As shown in Table 4.6, the simulation results indicate that with a full implementation of the COMESA FTA, the DRC will experience a consumer welfare gain amounting to US\$28.49 million. Iron and steel, especially corrugated is the highest welfare improving product with a value of US\$9.78 million, followed by wheat or meslin flour and maize (corn) flour which are valued at US\$4.42 million of consumer welfare gain. As noticed, the first-two welfare improving products represent roughly 50 per cent of the total increase in househols' savings.

In addition, products like quicklime and white cement, tobacco, light oils, coke or semi-coke of coal and other mineral oils, cane sugar, soap products, broken rice, prefabricated structural components for building, explosives and pyrotechnic products are expected to improve Congolese welfare by increasing households' savings at US\$7.63 million which represents approximately 27 per cent of the total welfare gain.

Interestingly, the welfare improving list includes products such as salt, quicklime and white cement, cane sugar, wheat or meslin flour, mineral oils, animal or vegetable oils and soap that were previously identified as trade-diverting products. This indicates the deleterious welfare effect of trade diversion (Schiff and Winters, 2003).

Overall, the welface impact of the COMESA FTA on the DRC will not be significant since it is expected to represent only 0.14 of 2010 GDP. This outcome is in line with Mugano (2015) who finds a welfare gain of 0.17 per cent of 2011 GDP in the case of Zimbabwe under the bilateral free trade agreement (BFTA) scenario with its top ten major trading partners.

\subsection{The Impact on Exports}

In general, a free trade area (FTA) allows countries which are the most efficient producers to export their domestic products. Consequently, an FTA is expected to lead to an increase in exports due to the trade barriers' dismantling.

Table 4.7 below presents the resulting changes on the DRC exports due to the COMESA FTA. The assessment from the WITS-SMART simulation model shows that the DRC's exports toward the COMESA region will significantly increase from US\$749.99 million to US $\$ 1,121.56$ billion (see Table 4.7). 
Table 87 : The Impact of the COMESA FTA on the DRC Exports (US\$ Million)

\begin{tabular}{|l|r|r|r|r|}
\hline Partner Country & Exports Before & Exports After & Change & \% Share of Total Exports \\
\hline Zambia & 333.445 & 465.743 & 132.299 & 41.53 \\
\hline Uganda & 183.965 & 302.892 & 118.927 & 27.01 \\
\hline Kenya & 161.350 & 253.072 & 91.722 & 22.56 \\
\hline Zimbabwe & 25.007 & 31.240 & 6.234 & 2.79 \\
\hline Rwanda & 16.358 & 28.631 & 12.273 & 2.55 \\
\hline Egypt, Arab Rep. & 20.434 & 24.467 & 4.033 & 2.18 \\
\hline Burundi & 7.236 & 13.038 & 5.802 & 1.16 \\
\hline Madagascar & 1.295 & 1.459 & 0.164 & 0.13 \\
\hline Malawi & 0.897 & 1.016 & 0.119 & 0.09 \\
\hline Total & $\mathbf{7 4 9 . 9 8 7}$ & $\mathbf{1 ~ 1 2 1 . 5 5 9}$ & $\mathbf{3 7 1 . 5 7 2}$ & $\mathbf{1 0 0 . 0 0}$ \\
\hline
\end{tabular}

Source : Author's Calculations Based on WITS-SMART Simulations.

As shown in Table 4.7, the major destinations for the DRC's export goods toward the COMESA region are mainly Zambia, Uganda and Kenya which absorb 91.10 per cent of total exports resulting from the FTA.

The three categories of commodities that will benefit from the export boom with over US\$100 million are mostly iron and steel (US\$143.05 million), quicklime, limestone flux, sulphur of all kinds, magnesite, salt and pure sodium chloride, hydraulic lime and bentonite (US\$111.14 million) and wheat or meslin, maize (corn) flour (US\$105.66 million) (see Table 4.8 below).

Table 98 : The DRC Major Exports after the COMESA FTA (US\$ Million)

\begin{tabular}{|c|l|r|}
\hline HS Code & \multicolumn{1}{|c|}{ Product Description } & \multicolumn{1}{c|}{ Value } \\
\hline 11 & Products of the milling industry, Malt and Wheat Gluten & 105.663 \\
\hline 17 & Sugars and Sugar Confectionery & 86.376 \\
\hline 72 & Iron and Steel & 143.052 \\
\hline 25 & Salt, sulphur, earth and stone, plastering material, lime and cement & 111.135 \\
\hline 27 & Mineral Fuels, Oils and Bituminous Substances & 59.699 \\
\hline 39 & Plastics and Articles Thereof & 50.127 \\
\hline 28 & Inorganic Compouds of Precious Metals & 93.004 \\
\hline 15 & Animal or Vegetable Fats and Oils & 35.541 \\
\hline 10 & Cereals & 22.305 \\
\hline 33 & Essential Oils and Resinoids; Perfumery and Cosmetic & 20.818 \\
\hline
\end{tabular}

Source : Author's Calculations Based on WITS-SMART Simulations.

In addition to the three major commodities, sulphuric acid and oleum, argon, oxygen, cobalt oxides and hydroxides will represente a value of US\$93 million, whereas coke and semi-coke 
of coal, light oils, electrical energy and natural gas will account for around US\$60 million. Other products manufactured in the DRC are also expected to be outsourced by the COMESA trading partners as a result of the FTA. These products are polymers of ethylene and other plastics, carboys, bottles, flasks and similar articles (US\$50.12 million), crude oil, margarine, glycerol, vegetable fats and oils (US\$35.54 million), broken rice, semi-milled or wholly milled rice, barley, seed and other similar goods (US\$22.31 million) and powders, shampoos and dentifrices (US\$20.82 million).

\subsection{The Impact on Imports}

To estimate the quantitative impact of the COMESA FTA on the DRC's imports is among the current study's objectives. The creation of a free trade area (FTA) increases trade between partner countries by allowing cheaper products from the bloc union to substitute for more expensive domestic production (Schiff and Winters, 2003). Consequently, an FTA will usually lead to an increase in imports as a result of lower prices.

In the case of the DRC, Table 4.9 below presents the estimated impact of the COMESA FTA on the DRC imports.

Table 109 : The Impact of the COMESA FTA on the DRC imports (US\$ Million)

\begin{tabular}{|r|l|r|r|r|}
\hline $\begin{array}{c}\text { HS } \\
\text { Code }\end{array}$ & \multicolumn{1}{|c|}{ Product Description } & $\begin{array}{c}\text { Imports } \\
\text { Before }\end{array}$ & $\begin{array}{c}\text { Change in } \\
\text { Imports }\end{array}$ & $\begin{array}{c}\text { Imports } \\
\text { After }\end{array}$ \\
\hline 27 Mineral Fuels, Oils and Bituminous Substances & 459.91 & 14.01 & 473.92 \\
\hline 72 Iron and Steel & 93.29 & 97.15 & 190.43 \\
\hline 11 Products of the milling industry, Malt and Wheat Gluten & 117.17 & 68.93 & 186.10 \\
\hline 25 Salt, Sulphur and Plastering Materials & 130.93 & 30.37 & 161.31 \\
\hline 17 Sugars and Sugar Confectionery & 104.75 & 8.56 & 113.31 \\
\hline 10 Cereals & 96.15 & 8.82 & 104.97 \\
\hline 34 Soap, Artificial Waxes, Candles and Similar Articles & 55.73 & 8.03 & 63.76 \\
\hline 24 Tobacco and manufactured Tobacco Substitutes & 12.49 & 8.73 & 21.23 \\
\hline 36 Explosives and Pyrotechnic Products & 12.37 & 3.52 & 15.89 \\
\hline 1 Live Animals & 7.33 & 6.19 & 13.52 \\
\hline Other & 2900.01 & 67.79 & 2967.80 \\
\hline Total & $\mathbf{3 9 9 0 . 1 3}$ & $\mathbf{3 2 2 . 1 0}$ & $\mathbf{4 3 1 2 . 2 3}$ \\
\hline
\end{tabular}

Source : Author's Calculations Based on WITS-SMART Simulations. 
The results based on the WITS-SMART simulation model indicate that the DRC imports are expected to increase by US $\$ 322.10$ million due to the COMESA FTA. This 8.07 per cent increased in imports is essentially driven by trade creation.

Major imports include mostly light oils and preparations, coke and semi-coke of coal in the mineral fuels, oils and bituminous substances category; corrugated among the iron and steel products; wheat or meslin flour and maize (corn) flour in the category of products of the milling industry, malt and wheat gluten; and quicklime, limestone flux; limestone and other calcareous stone, of a kind used for the manufacture of lime or cement in the category of salt; sulphur; earths and stone; plastering materials (see Table 4.9).

\subsection{Sensitivity Analysis and Robustness Tests on the Results}

The findings presented in the current study may be sensitive to assumptions made, that is, the Armington assumption and the actual values of demand elasticities. Therefore, in order to ensure the robustness of the results, a rigorous sensitivity analysis is conducted by re-running three others simulations apart from the main results identified as a 'base case'. Refering to the base case, lower and upper bounds are determined by changing various values of elasticities as defined in the methodology section (See table 3.1). In addition to lower and upper bounds, a 'worse case' scenario is establised by adding 4 to the upper bound values.

Table 1110 : Robustness tests and sensitivity analysis of the impact of the COMESA FTA on the DRC in terms of trade creation, revenue, welfare, imports and exports.

\begin{tabular}{|l|c|c|c|c|}
\hline Effects/Indicators & Lower bound & Base-case & Upper bound & Worst case \\
\hline Trade creation (US\$ million) & 322.10 & 322.10 & 322.10 & 322.10 \\
\hline Revenue (US\$ million) & -101.99 & -107.01 & -109.50 & -132.37 \\
\hline Welfare (US\$ million) & 28.78 & 28.49 & 28.34 & 26.79 \\
\hline Imports (\% change) & 8.07 & 8.07 & 8.07 & 8.07 \\
\hline Exports (\% change) & 45.16 & 49.54 & 51.73 & 71.15 \\
\hline
\end{tabular}

Source: Author's Calculations Based on WITS-SMART Simulations.

As shown in table 4.10, changing the elasticity of substitution to 0.5 will not change the trade creation effect of the COMESA FTA in the DRC comparatively to the base case. Similarly, the trade creation effect remains the same after increasing the elasticity of substitution to 2 and 6 . This result indicates that the total change in imports value remains unchanged, although its composition varies due to the substitution effect across different imports. 
However, reducing trade elasticity to 0.5 will reduce revenue loss by 4.69 per cent compared to the base case (see Table 4.10). Moreover, increasing the elasticity of substitution to 2 and 6 may increase revenue loss by 2.33 per cent and 23.70 respectively. Comparatively to the base case, the outcomes in upper bound and worst case simulations confirm the fact that the increased substitution effect across varies imports relative to price changes has an impact on revenue. The middle ground estimates could approximate the potential magnitudes since the sum of deviations on lower and upper bounds from the base case is not significant (2.36\%).

In addition, reducing trade elasticity to 0.5 will improve consumer welfare by 1.02 per cent, whereas increasing trade elasticity values to 2 and 6 will respectively reduce welfare benefits by 0.53 per cent in the upper bound scenario and 5.97 per cent in the worse case scenario. Again, the middle ground estimates could be fairly close to the potential magnitudes since the sum of deviations on lower and upper bounds from the base case is insignificant $(0.49 \%)$.

Further, reducing the elasticity of substitution to 0.5 will result in an increase of 45.16 per cent in exports, that is, 4.38 per cent less compared to the base case (see Table 4.10). After increasing trade elasticity to 2 and 6, exports will increase by 51.73 per cent in the upper bound scenario, that is, 2.19 per cent more than the middle ground estimate and 71.15 per cent in the worse case scenario, that is, a deviation of 21.61 per cent from the base case (see Table 4.10). Since the sum of deviations on lower and upper bounds from the base case is only around a margin error of 2 per cent, the middle ground estimates could be within the range of the potential magnitudes.

Finally, imports remain inchanged after reducing trade elasticity to 0.5 (see Table 4.10). Similarly, increasing trade elasticity to 2 and 6 shows no changes in imports relative to the base case. As noted previously, this outcome indicates that the total change in imports value remains unchanged, although its composition varies due to the substitution effect across different imports.

\section{Conclusion and policy recommendations}

The conclusion that can emerge from this study is that although joining the COMESA FTA may have some negative effects on the DRC's economy it would be trade creating and somewhat welfare improving. This welface impact may be insignificant since it will represent 
roughly 0.14 of 2010 GDP. The results also suggest that the COMESA FTA may lead to trade diversion in the DRC.

Notwithstanding the fact that trade creation will have a positive effect on welfare, as the Congolese consumers would benefit from lower prices, some local industries in the DRC may be threaten of closure due to the lack of competitiveness. The resulting trade creation may also pose a treat to government's fiscal revenue. Therefore, the significant revenue loss due to the COMESA FTA needs to be taken seriously given the fact that customs duties represent 50 per cent of government revenues in the DRC. Accordingly, it is imperative for the DRC's government to impove the tax-collection system or search for alternative source of revenues.

Considering the above-mentioned issues, the following policy recommendations can be drawn from this study :

First of all, regarding the local industry that could be threaten of closure due to the lack of competitiveness, the DRC's government needs to come up with a strategic plan in order to protect the national industry that would be negatively affected. This strategic plan should consist of various measures to alleviate the cost of foreign competition, thereby enhancing the competitiveness and profitability of the affected domestic industry. Since the COMESA FTA will be implemented progressively through a three-year phase down approach, the DRC's government could also use a sensitive list as a mean to protect domestic industries from foreign competition in the short run.

To mitigate the revenue loss, the implementation of the COMESA FTA in the DRC should be accompanied by fiscal reforms to improve the tax-collection system from sales or value-added taxes (VAT) and domestic excise. One of the fiscal reforms could be the diversification of VAT rates which was introduced since January 2012 with a single rate of 16 per cent. In addition, the Congolese government could also define a sensitive list as a mean to preserve tariff revenues in the short run, while working on fiscal reforms regarding domestic taxation. Finally, the government could broaden the tax base by taxing the informal sector which generates 94.58 per cent of labor income and represents 91.2 per cent of households consumption in the DRC (Congo, 2006). 
To counter the diversion effect resulting from the implementation of the COMESA FTA in the DRC, the country could draw up policy reforms which favour sectors where trade diversion exists such as salt, sulphur, earth and stone, plastering material, lime and cement; sugars and sugar confectionery; plastics and articles thereof; products of the milling industry, malt and wheat gluten; articles of iron or steel; mineral fuels, oils and bituminous substances; and animal or vegetable fats and oils. Therefore, the inefficient producers from the COMESA region could be displaced through building new capacities in short, medium and long term based on comparative advantage in order to address supply constraints in these sectors affected by trade diversion.

\section{Declarations}

\section{Acknowledgements}

I wish to express my acknowledgement to Dr Gift Mugano for his valuable advice and close guidance during the preparation of this study. I am also grateful to the German foundation ElseKröner-Fresenius-Stiftung and the Excellence Scholarship Program BEBUC for their partial financial support during my master study at Nelson Mandela University.

\section{Authors' contributions}

Lusenge N.P has reviewed the empirical literature of this research, identified the gap of knowledge related to this topic, conducted the analysis of the findings, and proved conclusion and policy recommendations.

Mugano G. has provided advice and guidance throughout the completion of this study, especially regarding the estimation of the model and the validation of the results.

\section{Funding}

Not applicable.

\section{Availability of data}

Data used in this study is available online from World Integrated Trade Solution (WITS) 2010 database.

\section{Competing interests}

The authors declare that they have no competing interests.

\section{References}

Amjadi A, Schuler P, Kuwahara H, et al. (2011) World Integrated Trade Solution : User's Manual, Washington, DC: World Bank.

Bacchetta M, Beverelli C, Cadot O, et al. (2012) A practical guide to trade policy analysis, Geneva: World Trade Organization (WTO).

Choudhry S, Kallummal M and Varma P. (2012) Trade Creation and Trade Diversion in the India-Sri Lanka Free Trade Agreement : A Sector Specific Analysis. Journal of Economic Policy \& Research 8(1): 36-61.

Congo. (2006) Document de la Stratégie de Croissance et de Réduction de la Pauvreté. In: Plan (ed). Kinshasa. 
COPIREP. (2012) Global ITCM apporte Usd 100 millions pour relancer la Sosider. Available at: http://www.copirep.cd/index.php/infos/actualites/111-global-relance-lasosider.

Drozdz J and Miškinis A. (2011) Benefits and threats of free trade. Ekonomia 2(14): 40-48.

Erero JL, Pambudi DD and Bonga-Bonga L. (2014) Effects of Reducing Tariffs in The Democratic Republic of Congo (DRC): A CGE Analysis. Economic Research Southern Africa. Working paper 467: 1-33.

Guei, K., Mugano, G., \& le Roux, P. (2017). Revenue, welfare and trade effects of European Union Free Trade Agreement on South Africa. South African Journal of Economic and Management Sciences, 20(1), 1-11.

Jammes O and Olarreaga M. (2005) Explaining Smart and GSIM. The World Bank.

Kumar S and Ahmed S. (2014) Impact of Sensitive Lists Under SAFTA: Quantitative Assessment Using a Partial Equilibrium Modeling. European Journal of Globalization and Development Research 10(1): 595-617.

Laird S and Yeats A. (1986) The UNCTAD trade policy simulation model. A Note on the Methodology, Data and Users. United Nations Conference on Trade and Development (Discussion Papers No. 19).

Makochekanwa A. (2014) Welfare Implications of COMESA-EAC-SADC Tripartite Free Trade Area. African Development Review 26(1): 186-202.

Mosley P and Chiripanhura B. (2009) Liberalisation and poverty in Africa since 1990-Why is the operation of the 'invisible hand'uneven? Journal of International Development 21: $749-756$.

Mugano G. (2013a) The Impact of Trade Liberalisation on Zimbabwe. Department Economics and Economic History. Port Elizabeth: Nelson Mandela Metropolitan University (NMMU).

Mugano G. (2015) A review of the impact of bilateral agreements on Zimbabwe. Journal for Development and Leadership 4(2): 88-103.

Onogwu G and Arene C. (2013) Adjusting Liberalization due to Trade, Revenue, and Welfare Effects: An Economic Partnership Agreement Scenario between Cape Verde and the EU. Journal of Agriculture and Sustainability 3(1): 87-107.

Osemo W. (2016) Sixteen Countries now in Free Trade Area. Available at: http://www.comesa.int/sixteen-countries-now-in-free-trade-area/.

Othieno L and Shinyekwa I. (2011) Trade, Revenue and Welfare Effects of The East African Community Customs Union Principle of Asymmetry on Uganda: An Application of Wits-Smart Simulation Model. Economic Policy Research Centre 1: 1-26.

Ousmane A. (2015) The Impact of the Economic Partnership Agreements between ECOWAS and the EU on Niger. Business and Economics Journal 6(2): 1-9.

Pereira, Gómez D and Herrera L. (2012) The colombia-canada free trade area: a partial equilibrium simulation. Semestre Económico 15: 15-42.

Plummer MG, Cheong D and Hamanaka S. (2011) Methodology for impact assessment of free trade agreements: Asian Development Bank.

Schiff MW and Winters LA. (2003) Regional integration and development, Washington, DC: World Bank and Oxford University Press.

Snorrason ST. (2012) The Theory of Trade Agreements, Economic Integration, Size of Economies, Trade Costs and Welfare. Asymmetric Economic Integration. Springer, 946.

Stern RM, Francis J and Schumacher B. (1976) Price elasticities in international trade: An annotated bibliography, London: Macmillan.

Tokarick S. (2014) A method for calculating export supply and import demand elasticities. The Journal of International Trade \& Economic Development 23(7): 1059-1087. 
WTO. (2010) Trade Policy Review Report by the Democratic Republic of the Congo. Geneva: World Trade Organization, 4-23.

WTO. (2016) Trade Policy Review Report by the Democratic Republic of the Congo. Geneva: World Trade Organization, 3-19. 


\section{Figures}

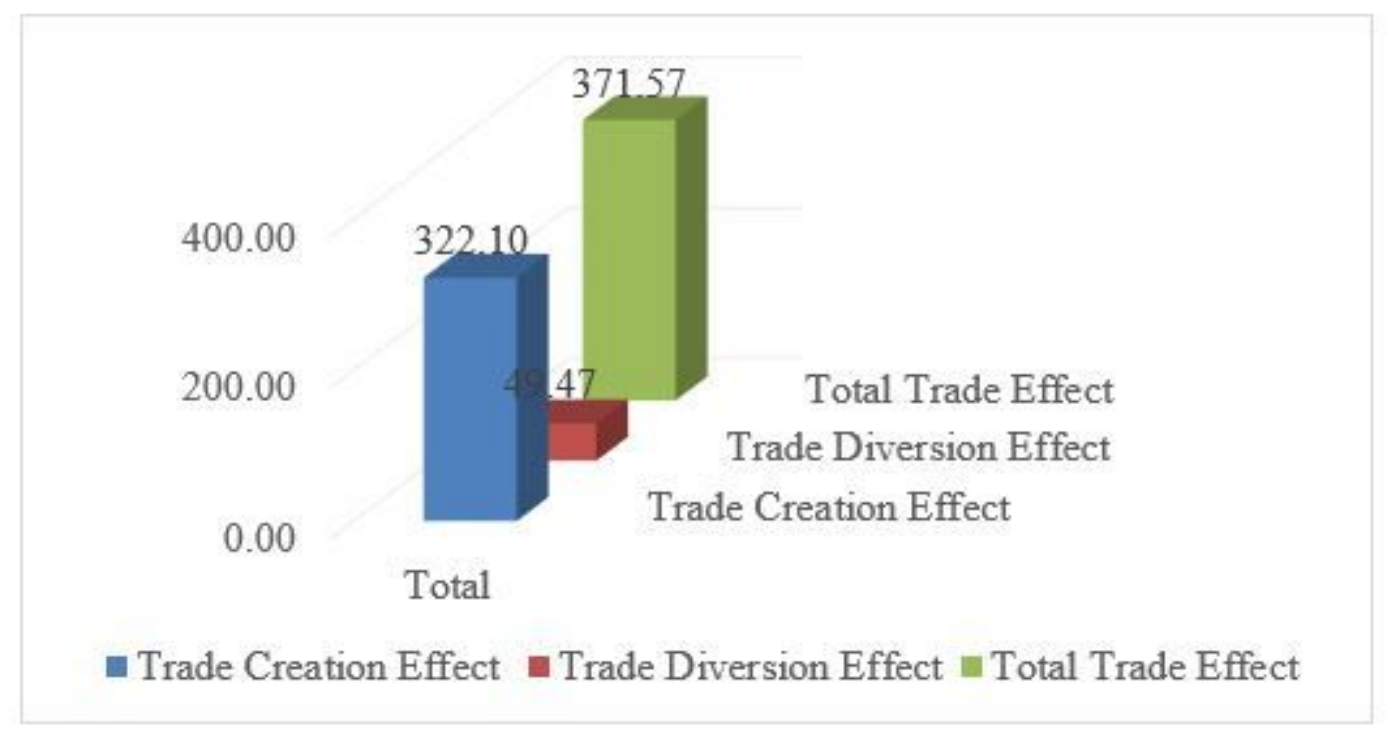

Source : Author's Drawing Based on WITS-SMART Simulations.

\section{Figure 1}

Trade Creation versus Trade Diversion Effects (US\$ million).

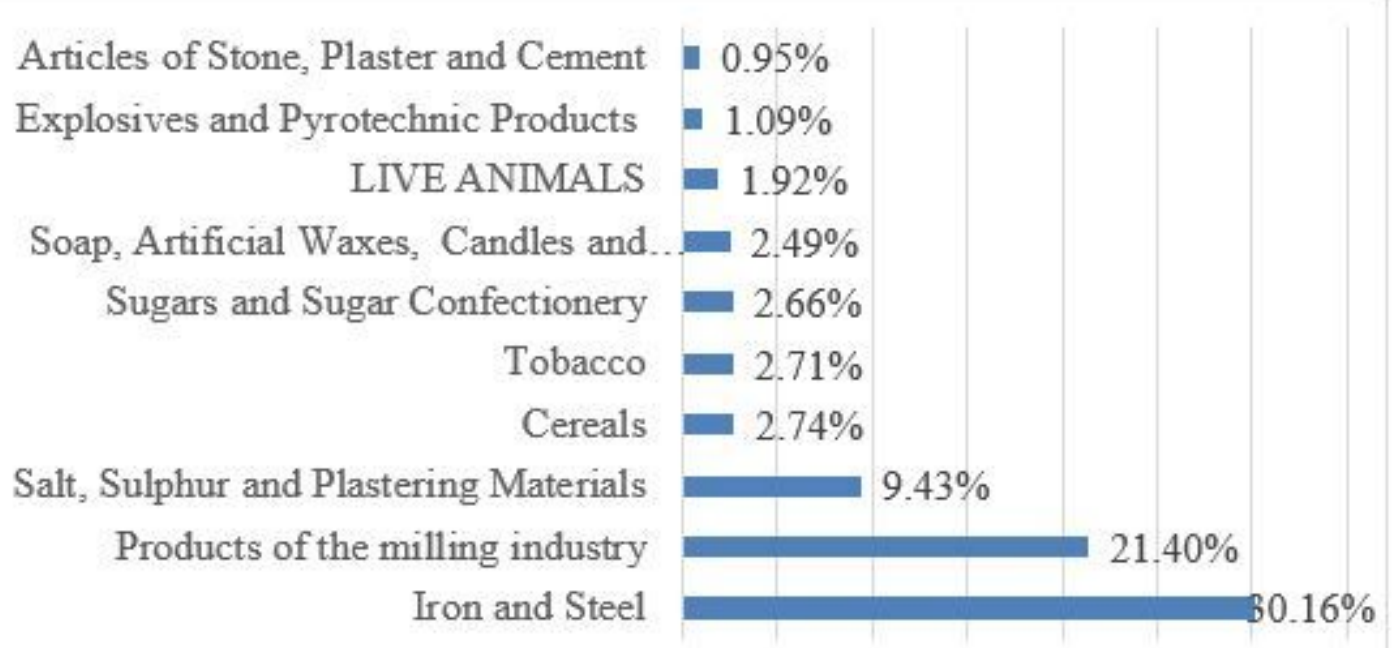

Source : Author's Drawing Based on WITS-SMART Simulations.

Figure 2

Share of the Top Ten Trade-Creating Products (\%).

\section{Supplementary Files}

This is a list of supplementary files associated with this preprint. Click to download. 
- Fulldescriptionofthemodelframework.docx 